\title{
"Playin' 'em like a Piana": Richard John Seddon and the Mastery of Public Performance
}

\section{TOM BROOKING}

\section{Introduction}

In late 1904 Premier Richard John Seddon showed great physical courage by confronting shopkeepers furious at his government's efforts to shorten opening hours. In a public performance, of which this enduring politician bragged that he played the crowd "like a piana," Seddon was able to subdue a hostile audience. Newspaper reports suggest that he received much flack at both an afternoon and an evening meeting from Opposition Members of the House of Representatives [MHR] as well as angry crowds. Furthermore, after leaving the Druids' Hall in Cuba Street, Wellington. Seddon received sustained booing from 200 to 300 people gathered outside seemingly unimpressed by his suggestion that they "keep their hair on." The evening meeting proved even hotter. He almost lost his composure at one point, before restoring order by repeating his suggestion that the declaration of "combined districts" (that is, the suburbs that would be included with the central areas of the main centres where hours would be restricted) could be delayed and a test case organized with the Department of Labour to hold back the legislation's introduction by another year. Even though the fiery meeting went on until the early hours of the morning, this act of courage and populist genius swung the audience around, and they ended proceedings by singing "For He's a Jolly Good Fellow."

By acting so promptly and directly the Premier took the heat out of the issue, quelled open popular rebellion and overcame what pro-Liberal papers such as the Christchurch Star judged "a class movement" led by people who did not understand the new law properly. ${ }^{3}$ Despite one letter writer claiming that such "Napoleonic" tactics had brought about Seddon's "Waterloo," he turned the tide of opinion in his favour through his quick thinking and ability to compromise by introducing less draconian legislation in 1905. As the New Zealand Times put it, the "excited indignation" soon "spent its force." Politicians had to be adept on the hustings and Seddon provides a case study of political rhetoric in action.

During the 1905 election campaign Seddon had to overcome noisy disruption orchestrated by the parliamentary Opposition in the Christchurch Town Hall. Through sheer lung power and physical presence he managed to drive off the hecklers, win over the crowd and march on to a record fifth consecutive electoral win, securing over $50 \%$ of the vote for the fourth time. ${ }^{6}$ No other New Zealand leader has so dominated one of the world's more vigorous democracies, in which both Māori and Pākehā women won the vote in 1893 after all adult males had won the franchise in 1889 (ironically all Māori men won the vote in 1867). ${ }^{7}$

Seddon apparently won broader and more sustained electoral support than any Prime Minister before or since without obvious linguistic playfulness or oratorical artifice. Indeed, according to some contemporaries and many historians, he achieved this level of dominance despite being a relatively poor public speaker. This article challenges such an assessment because it is based on British elite standards not necessarily shared by the bulk of the electorate. There were other popular speaking styles that had emerged, particularly in the United States of America. Seddon cannot readily be compared with such US Presidents as Andrew Jackson and Abraham Lincoln as an orator and rhetorician, but like these more democratically attuned politicians he shaped his public speaking to appeal to a broad audience. His approach can perhaps most accurately be compared with Theodore 
(Teddy) Roosevelt, who dominated American politics in the early twentieth century. ${ }^{8}$ William Ewart Gladstone also changed his approach to electioneering and his speaking style in the late 1860 s so he could appeal to mass meetings by incorporating some American elements. Seddon certainly knew all about Gladstone's broadening appeal, helped by constant stumping of the electorate by use of the rail network, even if their speeches cannot be readily compared. Seddon, for example, only very rarely introduced quotations in Latin and never in ancient Greek. ${ }^{9}$ There was also an older Chartist tradition of street oratory in Britain, continued by the Labour wing of the Liberal party, with which Seddon was familiar. He drew upon it, especially through his habit of singing songs chosen to meet the needs of particular audiences at the end of speeches. ${ }^{10}$ Critics of Seddon's public speaking, whether in the House or on the hustings, seem to have forgotten that, as Andrew Roberts, biographer of Hitler, Churchill and Lord Salisbury, and an historian of the English speaking world reminds us: "Oratory is not the same as an essay... it comes from the heart and the throat rather than the mind and pen... speeches are immediate, passionate, intimately of their time and above all spoken; they are thus not at all the same as literature."11 This article will utilize Roberts's criteria to challenge the orthodoxy as set out below concerning Seddon's speaking by examining some key speeches and performances across his long parliamentary career from 1879 to 1906.

\section{Contemporary Opinion of Seddon as an Orator / Public Speaker}

Seddon's colleague and author of the first popular history of New Zealand, William Pember Reeves, set the pattern by suggesting that this rough-hewn, former mechanical engineer from St Helens in Lancashire, who also worked as a gold miner, publican, storekeeper and gold miners' advocate on the West Coast of the South Island, was an indifferent public speaker. Many contemporaries shared this view, although by no means all. Seddon's conservative opponent, and big Canterbury land owner, Sir John Hall, for example, remarked in 1897 on his "real brains, leathery lungs, untiring energy and utter disregard of scruples." 12 From the other end of the spectrum the Fabian socialist Beatrice Webb judged him "a gross, illiterate but forceful man." ${ }^{13}$ A little later, in a typically acerbic editorial, the Evening Post, of Wellington, suggested that his "Manifesto on Humanitarianism," produced during the 1905 election campaign, was "too poetical" to have been written by Seddon. ${ }^{14}$ On Seddon's death on 10 May 1906 an "ex-New Zealander" described him to the Sydney Morning Herald as "a forceful and fluent speaker," but not an orator. ${ }^{15}$ Similarly, the stridently republican Sydney-based Bulletin, which admired Seddon's progressive social policies but abhorred his support of the Boer War, complained that his "speeches were always too long." 16 Reeves, in the first four editions of his very popular general history of New Zealand, The Long White Cloud, first published in 1898, entrenched this view by writing: "Of his speeches enough to say that their number, bulk and lack of quality were a serious obstacle to his rise in political life ... he managed for eleven years to talk so much and say so little." Reeves added that he "laid about him with a club."17

Historians have generally agreed with Reeves, the Webbs, and other contemporary critics. Even Seddon's hagiographer James Drummond proclaimed: "He was no orator. He did not stop to pick and choose his sentences. They came in a full flood of tumbling words, rushing along with a great sound, like many waters." 18 The Keynesian economic historian J. B. Condliffe and the Marxist Willis Airey, in their popular interwar Short History of New Zealand, cemented the Reevesian view by telling a generation of schoolchildren that Seddon was "no scholar and had few of the graces of the cultured man."19 J. C. Beaglehole reinforced this judgement when he wrote in typically flamboyant prose in New Zealand: A Short History published in 1936: "[Seddon] united within himself a whole orchestra, or, 
rather, brass band, of achievement; and as a performer on the big bass drum he was without a peer. Yet the noise did, it must be noted, signify something. " ${ }^{20}$ In A History of New Zealand, (1959) Keith Sinclair followed Reeves's and Beaglehole's lead in accusing Seddon of "clumsy verbosity." 21

Then there was the matter of voice and dialect. Seddon had a powerful and rather mellifluous baritone voice, but his Lancashire accent assaulted the ears of politicians who hailed from the south-eastern corner of England as much as the Highland burr of Minister of Lands John McKenzie, the Northern Irish lilt of Seddon's predecessor Premier John Ballance or the nasal twang of New Zealand-born politicians. Complaints about Seddon's broad dialect probably tell us more about the inability of listeners from southern England, who made up a clear majority of English immigrants in New Zealand, ${ }^{22}$ to appreciate any kind of unfamiliar northern accent, than they do about the accent itself. This is very obvious in the shocked manner with which English school inspectors, all of them from London or southern counties, complained about regional accents in a major report on the standard of speech in schools published in $1861 .{ }^{23}$ Seddon certainly dropped his "aitches" in a manner that would have offended Henry Higgins, and played up to the local audience at a banquet held in his honour in St Helens in 1902 announcing "Aw've Coom Whoam.","4 Even so, the St Helens accent is in fact one of the softest in Lancashire. This point is underscored by the speech "impersonator" who fooled an audience of 700 people, including all the reporters, at a meeting in Nelson in 1905 into thinking that they were listening to an apology for non-attendance from the Premier. ${ }^{25}$ The baritone voice on this ancient recording is strong and firm but the accent is quite gentle. Talking to octogenarians brought up in St Helens confirms that the impersonator got it right. ${ }^{26}$

Of course, the numerous complaints made by Seddon's conservative opponents in the 1880s reflect the fact that most came from the south and judged any accent other than the accepted form of English, so mercilessly parodied by George Bernard Shaw, as lower class and coarse. The posthumous publication in 1892 of the work of the pioneer scholar of phonetics Alexander John Ellis reinforced such judgemental approaches to speech by introducing the notion of "received" pronunciation and suggesting that only uneducated persons spoke in dialect. ${ }^{27}$ Class distance, snobbery and the southern Englishman's aural intolerance and preference for a certain way of speaking undoubtedly exaggerated stories of the coarseness of Seddon's voice. On the other hand, as a young man working in St Helens and Liverpool, Seddon must also have noticed that both employers and politicians often spoke to their workers or audiences in dialect to enhance their popularity and to ensure that they were understood. ${ }^{28}$ This provides a clue as to his effectiveness with live audiences: he learned to speak to them in a language that they understood.

\section{A Reconsideration}

There is something of a serious disconnect between the majority historians' views and Seddon's considerable and long-lasting popularity. If he really was such a poor public speaker Seddon could not have dominated New Zealand politics for so long. Surely only hard-core party loyalists could have enjoyed speeches of 70 minutes, and often longer, if they had been quite so dreary? Indeed, his plain and fact-laden speeches have better stood the harsh test of time than many of those delivered by politicians rated as top-drawer orators of their day. Seddon's hagiographer James Drummond, for example, compares Seddon unfavourably with former governor, "father" of the Liberal party, and short-lived premier, Sir George Grey. Yet to the modern reader Grey seems a pompous exponent of "high rhetoric" that seldom made much sense to his contemporaries, let alone historians. ${ }^{29}$ The Catholic newspaper The New Zealand Tablet, supporting Seddon's assumption of the 
role of Premier in 1893, claimed that he spoke "sound common sense" whereas Sir Robert Stout uttered "high falutin' 'gush'.,"30

A minority of historians have, in fact, challenged the Reevesian assessment. William Parker Morrell, in his long-forgotten but balanced and insightful New Zealand (1935), remarked: "No democratic leader has ever excelled Seddon in making it appear to the people that he was indeed one of themselves and thought as they thought." ${ }^{, 31}$ Similarly, W. H. Oliver noted in The Story of New Zealand (1960) that Seddon "played the whole country like a piano, and seldom did his hands fall upon discordant notes." "More recently Gavin McLean has argued that Seddon was "the first New Zealand populist politician to outsmart people by appearing dimmer than he was." 33 One way of examining this discrepancy between the highly popular and hugely successful democratic politician and the inept public speaker, therefore, is to look at some key speeches amongst the thousands he made both in the House and on the hustings.

\section{Seddon's Maiden Speech}

Seddon's maiden speech of 2 October 1879 took nearly two hours to deliver. This first parliamentary performance was closely assessed because commentators have long believed that this set piece can reveal much about the prospects of new politicians. Parliament is also a kind of theatre in which politicians act out prescribed roles. The response of other politicians and the press depends as much on the politicians' acting ability as their capacity as debaters and public speakers. The length of Seddon's speech alone forced both parliamentarians and some newspaper editorialists to take note, whether they responded with admiration or disgust. Conservative papers such as the Otago Daily Times and the Christchurch Press, reported it in extremely abbreviated form without bothering to comment. ${ }^{34}$ The New Zealand Herald of Auckland usually sided with other conservative papers, but on this occasion seemed slightly more impressed by observing that Seddon "spoke with immense force." Although he caused much "laughter" by the manner in which he "scattered his aspirants," the Herald's parliamentary reporter judged it to be a "hard hitting" speech "greatly relished by the House."35 The editorial in Wellington's equally anti-Liberal newspaper, the Evening Post, complained in the manner typical of the lofty tone adopted by late nineteenth-century editors, that "he murders Her Majesty's English" and was "not pleasant to listen to." In contrast, the parliamentary reporter of the same paper who listened to parliamentary debate rather more frequently judged him to be a "man of common sense." ${ }^{36}$ Its morning contemporary the New Zealand Times (yet another conservatively inclined newspaper before the Liberal party purchased it in 1891), anticipating that Seddon, like most West Coast Members of the House of Representatives, would only last one parliamentary session, published a none-too-subtle satirical poem entitled "Blank M.H.R.," which began "Oh, Blank came out of the West; / Through all the Assembly there's no greater pest" and ended "Ho! Come ye to meddle, or come ye to mar, / Or to scatter your h's, big blank M.H.R.?",37

Yet, despite the largely parochial content and the indifference or condescension of many conservative papers, as the West Coast Times and others noted, it was an interesting speech that "made a favourable impression." 38 It has travelled across time fairly well to a citizen of the twenty-first century because its range and defiant tone reads better than many of the ornate and more highly regarded speeches made by some nineteenth-century politicians. The New Zealand Herald reporter got it right.

Although Frederick Alexander Whitaker, son of the powerful Auckland banker and land developer Frederick Whitaker, described the speech accurately as "voluminous and discursive," several core popular Liberal and Chartist tenets can be found amongst Seddon's long lament concerning neglect of Westland by successive governments. The 
high, moralistic tone was also very similar to that of both Gladstone and Grey, as well as to that of the Reverend Rutherford Waddell, as discussed elsewhere in this issue by John Stenhouse. ${ }^{39}$

Seddon began by stressing that manhood suffrage, operating on the principle of one man, one vote, had worked well in the goldfields electorates. He moved on to claim that the large centres of population, with the exception of Dunedin where the Scots had reputedly always been hostile to gold miners, supported Grey and his allies. He soon turned to advocating the special needs of the West Coast after accusing Canterbury of playing Shylock by extracting its pound of flesh and robbing the new Westland County Council of sufficient funds to build public works and improve tail-races. John Hall came in for special criticism because he had served as the foundation chairman of Westland County Council even though the miners had petitioned against the establishment of any such body. Seddon then attacked Alfred Saunders, MHR for Nelson and long-time advocate of temperance, for dismissing the young supporters of Grey as "greyhounds." He surprised a few politicians by quipping that like Mrs Malaprop he considered such comparisons to be " 'odorous'." After defending Grey against charges of senility, Seddon warned the House that his motto thereafter would be "No Surrender." Rather than sitting down he turned somewhat audaciously to expressing his views on the troubles at Parihaka.

After admitting that race relations difficulties would take 50 to 100 years to sort out properly, he suggested that ending confiscation and paying Māori a fair price for their land would help ease the tension. On the other hand, he did not think it fair that settlers had to pay the improved price and he wanted the land laws amended to stop them working "for the benefit of a favoured few."

Having settled that difficulty, Seddon somewhat immodestly defined himself as a "true definition of Liberalism" even if he would be called a "radical" in the "Old Country." Like the Chartists he wanted manhood suffrage introduced so that the broad-based electorate could throw out "the party of wrong doing." A long harangue followed about Hall's party persuading the Grey Valley MHR Edward Masters to change sides by holding out the lure of public work for his electorate. Seddon concluded this tirade by declaring, in a deliberate swipe at the Latinate pretensions of his opponents, "When once I take up a position I will fight it out to the last; I will never cry 'Peccavi'; though I will never ask for quarter for myself." 40

He moved to suggesting that most politicians should follow Grey's example and try to avoid making bad law like that made in other countries such as Ireland. Equally, good law should be followed, such as that of Victoria and New South Wales in relation to introducing a lower gold duty. He then attacked the land system operating in the Colony, claiming that bad and oppressive law had driven out the many grieving families he had seen making sad farewells on the Liverpool docks. He warned that unless such laws were reformed in New Zealand, settlers would be driven away to Victoria and New South Wales, where the Government had legislated against the power of the "squattocracy" by granting miners universal manhood suffrage. After another quick comment on native land policy, to the effect that settlers should not be crippled by having to pay high prices to secure land bought from Māori, he concluded that the electoral roll could be expanded at little cost, and condemned as undemocratic the current system in which small electorates containing only a few hundred people dominated Parliament. Even though the majority of the people had voted against Hall he still led the country because he had won more of these small electorates than Grey. New Zealand must, he warned, avoid the "rule of the minority." 41 In short, the speech is full of ideas consistent with "popular Liberal" beliefs espoused by many New Zealanders in 1879: Seddon told his constituents exactly what they 
wanted to hear, even if most politicians in the House ignored the long speech of such a political novice despite it containing a few deft touches.

\section{The 1881 Stonewall}

Seddon spent most of 1880 and 1881 protesting Hall's attempt to limit the effect of enfranchising every man over 21 who had lived in the colony for 18 months in the same electoral district. Under the "Qualification of Electors Act" passed by Hall in 1879, not only had the right of property owners to vote in two electorates been retained, but the value required of property had been lowered. Before then an elector had to own more than $£ 50$ of freehold in two different electorates; now he only had to own $£ 25$ worth. An increase of seven seats, so that 91 rather than 84 MHRs sat in the Lower House of the tiny colony, further increased the likelihood of plural voting. This heavily qualified reform clearly represented an act of giving with one hand while taking away with the other. Hall's reluctance to embrace democracy thereby gave Seddon, and other more radically inclined MHRs, powerful reason for stonewalling on an unprecedented scale.

In late August 1881, after Richard Reeves, MHR for the Grey Valley, had kept a small and exhausted House awake all night, Seddon arrived on 1 September and proceeded to go over every name on the Hokitika electoral role down to the letter " $K$ " to discuss how Hall's "reforms" would affect each individual. He also tried to abolish the freehold qualification and affirmed the principle of one man, one vote, making a rather remarkable reference to Plato's Republic. In a moment of democratic passion Seddon suggested that, like Plato, Hall and his supporters hoped that only "gold" persons, that is, a ruling class of well-educated big property owners, should control politics and prevent the "bronze" category of labourers and artisans from ever playing any part in running the country. ${ }^{42}$ Eventually, these opponents of Hall alienated the majority of the House and had to accept defeat on 3 September. ${ }^{43}$

Seddon's stonewall and democratic outburst had made him thoroughly unpopular with the political establishment. The conservative press harangued him. The Otago Daily Times described him as "a grotesque caricature of a legislator" and complained about "His want of education," "his entire ignorance of the subject he professes to be talking about" and "his Lancashire brogue." 44 Sneering reports in the Christchurch Press, which sent up his dialect mercilessly ("Hit is true, sir, that I had paired on the Bill with the Honourable Native Minister, but not on this here hitem"), ${ }^{45}$ so incensed Seddon that he read out a prepared speech denying that he used offensive language. Seddon complained that he could not believe that any newspaper could publish a statement "so evil, so exaggerated and incorrect." He suggested that even the notoriously sensational Police News of London would not lower itself to publish such an accusation before making a linguistic gesture towards his opponents by quoting Shakespeare in his own defence:

Who steals my purse, steals trash; 'tis something, nothing;

'Twas mine, 'tis his, and has been slave to thousands:

But he, that filches from me my good name,

Robs me of that, which not enriches him,

And makes me poor indeed. ${ }^{46}$

Seddon's first biographer R. M. Burdon claimed that Seddon only used such quotations as decoration. ${ }^{47}$ Certainly this is an awkward choice of speech, made by the evil and manipulative Iago to the honourable but naïve Othello. Yet the fact that it appears at all suggests that Seddon deliberately used the rhetoric of other popular Liberals and was fully aware of the dramatic impact that quoting Shakespeare had upon any audience. He at least knew how to source telling quotations to impress an audience familiar with the use of such 
devices, although direct references to Plato are unusual, even amongst Liberal or more radically inclined MHRs. ${ }^{48}$ Most "popular Liberals" were autodidacts who taught themselves through whatever means was available, but they tended to read a shared set of texts. The Bible and The Pilgrim's Progress held central place, as did the poetry of Robbie Burns and Thomas Babington Macaulay's History of England-four texts with which Seddon was thoroughly familiar. Like many other Liberals he supported the moralism of the Bible and The Pilgrim's Progress, adopted some of Burns's more radical notions, and agreed with Macaulay's "whiggish" contention that Britain had set itself upon a course of "improvement" in terms of securing increased material comfort, elevating moral behaviour, advancing civilization, and achieving constitutional and political progress by gradually becoming more democratic. ${ }^{49}$ Supporters of popular Liberalism also tended to read the same group of poems: selected Chaucer, Phillip Sidney's lyrical sixteenth-century verses, Shakespeare's sonnets, John Milton's epics from the era of the English Revolution, Oliver Goldsmith's “The Deserted Village," Thomas Gray's "Elegy Written in a Country Churchyard," and the works of many other long-forgotten minor poets such as George Crabbe. Seddon's personal library, now held at Victoria University of Wellington, includes a large anthology of English verse. The poems he has marked include some of those listed by the leading historians of popular Liberalism-Eugenio Biagini and Patrick Joyce — as the shared reading of supporters of popular Liberalism. ${ }^{50}$

\section{Seddon, Tom Paine and the 1890 Strike}

In June 1890, as a bitter strike of wharf labourers intensified, Seddon followed the leader of the Liberal party, John Ballance, by making a rousing speech attacking monopoly in all its guises, from land ownership to control of shipping and finance. He quoted directly from Tom Paine's "Declaration of the Rights of Man" concerning rights of "liberty, property, security, and resistance of oppression" and warned that unless government instituted reforms, a revolution from below threatened the struggling colony. He established the extent of land monopoly by listing numerous figures from a pamphlet written by $\mathrm{H}$. W. Farnell, a prominent Auckland-based supporter of the Californian land radical Henry George. Seddon shared the Californian reformer's prognosis concerning the ills of capitalism, but remained consistent in dissenting from George's solution in that he always advocated a combined land and progressive income tax rather than a "single tax" on land alone. Seddon reinforced the point that he was not a Knight of Labour, nor a "George-ite," by suggesting that only the kinds of solutions proposed by John McKenzie, that is some combination of land and income tax, could rescue New Zealand from a calamity like the French Revolution. He countered Hall's claim that the Opposition was made up of "unthinking men" by promoting his colleagues as "giants" as compared with the "pigmies" who supported the government. ${ }^{51} \mathrm{He}$ concluded that "Our country is one of the best under the sun. There is only one thing wrong: the land is in the hands of the few instead in the hands of the many" and added that financial and transport monopolies had destroyed confidence and "undermined the living conditions of most New Zealanders." 52 Clearly Seddon was very much in touch with the intricacies of the complex debates concerning land distribution and tenure of this era, and knew that Paine still held much currency with the skilled working classes. ${ }^{53}$

The fact that Seddon also followed up many speeches with a song or two, in the best Lancastrian tradition, ${ }^{54}$ further cemented his appeal by adding to the sense of performance-Seddon was an entertainer as much as a politician. Sir John Hall's loathing of this habit provides another key to understanding why Seddon ousted the old elite so effectively. ${ }^{55}$ It also helped that he matched the song with his audience. When on the West Coast with Catholic Irish voters in mind he sang the pro-Fenian song 'The Wearing O' the 
Green," whereas during his recruitment for the Boer War he gave a rendition of "Now We Are Britons."

\section{Invoking Macaulay at Queen Victoria's Diamond Jubilee of 1897}

Seddon caught the attention of the British press soon after his arrival in London by invoking Thomas Babington Macaulay's famous quote (condemned by Punch magazine as a cliché) about a visiting New Zealander sketching the ruins of St Pauls from a seat on London Bridge. Seddon protested that Macaulay had got it all wrong because "Little the historian knew of the New Zealander! If the Empire was to fall, the New Zealander would fall too." $" 56$ Such sharp awareness of the history of the Empire's capital city won Seddon an advantage over all the visiting Australian premiers. Thereafter the British press treated him as something of an exemplar of loyal colonial leader, whose opinions on the state of contemporary London were worth hearing, and interviewed him regularly. ${ }^{57}$

Although in its often cruel cartoons Punch poked fun at the rough colonial's lack of refinement thereafter, especially compared with someone as polished as Wilfred Laurier of Canada, other correspondents from papers such as Melbourne's Argus judged that Seddon had generally done a good job, and maintained an admirably sensible and nonpartisan approach to problems. ${ }^{58}$ Furthermore, even the Punch cartoons made Seddon much more widely known. Their satirical content was no worse than that he had already learnt to counter, laugh off or ignore in New Zealand. Like most successful populists he regarded all publicity to be good publicity, was quite happy to provide good copy, and revelled in his notoriety with the privileged. Secretary of State for the Colonies Joseph Chamberlain's quip about his "booming eloquence" only added to his prestige with the majority of the New Zealand electorate. ${ }^{59}$

\section{Cruising the Pacific in 1900}

In 1900 Seddon, along with various family members and friends, undertook a tour of the Pacific to help New Zealand establish a sub-empire in the region while restoring his ailing health. This time, though, he left the written account of the adventure to the undersecretary of Labour and prominent ethnographer Edward Tregear. The trip mimicked the visits of a royal and decidedly imperial entourage, and pushed the New Zealand case to the Colonial Office in dramatic fashion. The ensuing publication of a 445-page book, replete with over 120 photographs of exotic Pacific scenes, made the entire colony, as well as the Australian and British authorities, aware of the Premier's adventures. This detailed account makes clear that Seddon attempted to appeal to his Polynesian as much as his European audience. He always dressed up to deliver many lengthy speeches, sometimes wearing his blue privy councillor's uniform, flew and draped flags over potential members of New Zealand's subempire, and engaged enthusiastically in the feasting that followed oratory. Sometimes his daughter May also wore her khaki "Kaikori Girls' Corps" uniform to show off the superiority of colonial womanhood. These efforts, with their decidedly Gilbertian overtones, seem rather comical to later-day historians, just as they did to some contemporary satirists. Yet Seddon had already learnt from his extensive 1894 tour of remote Māori pā in the North Island that Polynesians liked ceremony, oratory and feasting and admired uniforms and flags. Seddon learnt further from constant meetings on marae in 1898 and 1899 that Māori valued whānau; so he brought a significant representation of his family along with him. He also referred to his "substantial" size, realizing that physical size (he carried around 135 kilograms on his six-foot frame at the time of his visit) conferred mana in Polynesian culture. From the British perspective, dressing up and delivering long speeches in sweltering heat was also correct behaviour for would-be imperialists. More importantly, as John Darwin argues, both the book and the tour were 
"meant to jog London's elbow and assert New Zealand's claim as the real trustee of the British interest in the South Pacific."60

\section{Promoting Women's Suffrage at the 1902 Coronation of Edward VII}

Edward VII's coronation provided Seddon with an occasion to forward New Zealand's reputation, and the drama of women's suffrage suffused his performances. Few of his listeners realized that this was somewhat ironic given that he had tried to delay its introduction in 1893, but once the change became a reality he promoted it with enthusiasm and even eloquence. He told the Central Society for Women's Suffrage in London and the Irish Woman's Suffrage and Local Government Association in Dublin, that he had been mistaken in his initial opposition to women's suffrage:

In matters of social reform, the care of children and of the aged and afflicted, the women of the colony had taken the deepest interest. The effect of the change upon the elections had been most gratifying. Since the passing of the Act the hotels were closed upon election days, canvassing was stopped, electors on their way to the poll could not be interrupted, and all was safeguarded in such a way that women could go to vote for a member of Parliament with the same safety and propriety as though they were going to a place of worship. Both men and women felt the responsibility which was cast upon them, and in that respect the granting of the franchise to women had had most beneficial results. It also had a preventive effect, for it prevented a man who had the slightest stain on his moral character from becoming a candidate for Parliament, because he knew that he would not have the least chance of being elected. Upon the liquor question women's influence would be felt, for they and their children were the chief sufferers in connexion with that matter, and there was no doubt that they would use their influence to promote a proper control of the sale of intoxicants. ${ }^{61}$

The one-time opponent of women's suffrage thereby became something of a darling of the British feminist movement and championed this cause as yet another of many progressive policies pursued by his enlightened government.

\section{An Almost Poetic Defense of Scenery Preservation.}

In 1903 Seddon surprised many contemporaries, who thought of him as a politician committed to development, by passing an Act to preserve scenery. In arguing for legislation to achieve this goal Seddon produced a few poetical moments that have surprised historians as well as his contemporaries. The Premier urged that "historic and beautiful places should be for all time conserved," otherwise his generation of politicians would be "wanting in our duty not only to ourselves, but to future generations." $\mathrm{He}$ enthused: "There are beautiful gorges and bush scenery, with the light and dark shades of green interwoven with the purple flowers of the rata, and the white flowers of the kumara, and of the other flowering trees in our forests." ${ }^{62} \mathrm{He}$ concluded: "I could wander in the bush and there conjure up old associations and scenes and for the time being live in the past; but one cannot do that if the past has disappeared by the destruction of the bush."63 He thereby showed that is possible for a pragmatic, populist politician to have aesthetic appreciation. After all, Seddon's mother instilled in him a love of Burns, whose poetry portrays humans as "a destructive force on earth" 64 and calls for people, whatever their social rank, to engage in a more organic relationship with the natural world. ${ }^{65} \mathrm{He}$ also wandered around the elegant parklands of Knowsley Estate as a small boy, and noted how much he preferred such an environment to the grime and stink of industrial St Helens. ${ }^{66}$ And he made it clear many times in interviews that he left the Railway Workshops in 
Melbourne for gold mining on the West Coast because he preferred the great outdoors to the confines of the factory. ${ }^{67}$ Besides, he had encountered the wilderness in its full, pristine glory and knew what had been lost. Indeed, he was one of the most widely travelled individuals in the colony, who had seen most parts from train and steamer as well as from the ground up; he knew New Zealand better than just about anyone else. e had also seen at first hand damage caused to the Buller Gorge, the Whanganui River and many other scenic areas by erosion triggered by the reckless removal of native forest.

\section{Wowing Australia in 1906}

Seddon proved just as popular with Australian as New Zealand audiences when he barnstormed through the country like an ageing music hall star in the last phase of his life. Many Australians had reacted grumpily to his government's decision not to federate in 1900, but he seems to have been forgiven by 1906. Audiences and journalists in Sydney, Melbourne, Ballarat, Bendigo and Adelaide adulated him. His version of "white" "practical utopianism,"68 especially his tirades against monopolies, Germans in the Pacific, and the Chinese, seemingly held enormous appeal. No one complained about the length of his speeches, and the accolades heaped up. Audiences became directly involved in his speeches, as the following report of an address to New Zealanders living in Sydney makes clear:

the guiding star of their life in New Zealand was that they should exercise all that was good, promote all that was righteous, and exercise the great power our Creator had given us for the good of mankind. (Cheers) The people of New Zealand desired that there should be equal opportunities. It was wrong that there were so many starving millions in England. This was not the fate of the selfgoverning colonies. (Cheers) ... our Creator did not intend the good things of life for only a few ... and the majority should not live a life of necessity "from the cradle to the grave". 69

When he died en route for New Zealand a few hours out of Sydney on 10 June 1906, Australian journalists, politicians and unionists claimed him as one of their own and even named a Melbourne suburb after him. His vision and style were clearly transportable to Australia.

\section{The secret of Seddon's success as a political performer}

Clearly, even if Seddon's spoken output was nowhere near as turgid and barren as some contemporaries and historians have suggested, it still had limited literary merit. Yet a close examination of some key texts produced across the entire range of his long career suggests that his constant speaking and occasional writing proved most effective with his target audience, partly because it was so unlike the "high" rhetoric disconnected from the great majority of the electorate that the likes of George Grey, Scobie Mackenzie, Sir Robert Stout, or Reeves himself employed. His plain speaking also took advantage of what Ian Pindar calls the "breakdown" of the "system of privilege," in which "ordinary men and women previously disqualified from public speaking seized the opportunity to address a crowd." $" 70$ Above all, Seddon had an uncanny knack of telling an audience what they wanted to hear and making them feel valued and special; his approach was very inclusive, if the listener happened to be a white settler. His speeches were also intelligent and he had a good command of detail, helped by the notes and headings he made that have survived in the Seddon Papers held at the Alexander Turnbull Library. This detail provided a sense of substance often lacking in the more ornate speeches of his political opponents. His electoral success also reinforces the fact that the elusive quality we call charisma-sheer 
force of personality and an effective delivery-proved at least as important as content in winning over voters. Politics provided a major form of entertainment before the advent of moving pictures and radio and Seddon always produced a dramatic performance.

Yet, although he had a highly tuned, populist antenna for the limits of his audience, he also could sketch out a clear vision for progressive change that he expressed in a passionate manner. His ideals appealed to a wide group of voters, both in terms of occupation and denomination. Struggling and would-be small farmers, many small-town businessmen and skilled workers found his message particularly appealing, as did their wives after 1893. His broad church Anglicanism also appealed to many Catholics, those Presbyterians who opposed the prohibitionist views of the likes of Rutherford Waddell, the Jewish community and even some Methodists. In addition to being a master of "the art of the possible," he was also expert at identifying "enemies" and folk devils, whether the Chinese, Asians in general, monopolists of land and wealth, privileged elites, or the indigent who did not deserve state assistance. In this instance his "club" was more effective than the rapier used by Reeves.

Overall, his command of theatre and live performance proved more significant than oratory, especially as he gave so many performances by stumping the electorate from one end of the country to the other on ships, in trains and on horseback, and attending so many banquets, more than any Prime Minister before or since. His speeches clearly came "from heart and the throat rather than the mind and pen" and were "immediate, passionate, intimately of their time." Morrell's long-forgotten assessment is consequently much more insightful than that of the more self-consciously intellectual Reeves, Beatrice and Sidney Webb, and Beaglehole, who never experienced the visceral delights of Seddon's performances for so many appreciative audiences in such a bewildering array of places.

\footnotetext{
${ }^{1}$ Evening Post, November 17, 1904, 2.

${ }^{2}$ Evening Post, November 17, 1904, 5.

${ }^{3}$ Star [Christchurch], editorial, November 17, 1905, 2.

${ }^{4}$ Edwin Edwards, New Zealand Herald, November 21, 1904, 6.

${ }^{5}$ New Zealand Times, November 18, 1904, 4.

6 Press, November 30, 1905, 6; Auckland Star, December 1, 1905, 3; Evening Post, December 5, 1905 , 7.

${ }^{7}$ Leslie Lipson, The Politics of Equality: New Zealand's Adventures in Democracy (Wellington: Victoria University Press, 2011), 174; David Hamer, "Richard John Seddon," in Dictionary of New Zealand Biography, Vol. 2, ed. Claudia Orange (Wellington: Bridget Williams Books and Department of Internal Affairs, 1993), 447-51.

${ }^{8}$ See Edmund Morris, Theodore Rex (New York: Random House, 2001; for analysis of Roosevelt's speech “An International Police Power," see Ian Pindar, The Folio Book of Historic Speeches (London: The Folio Society, 2007), 164-67.

${ }^{9}$ On Gladstone's change of approach, see Eugenio F. Biagini, Liberty, Retrenchment and Reform: Popular Liberalism in the Age of Gladstone (Cambridge: Cambridge University Press, 1992); for analysis of Gladstone's speech "You cannot Fight against the Future," see Pindar, Folio Book of Historic Speeches, 147-49.

${ }^{10}$ On the Lancastrian tradition of singing on the electoral platform, see Patrick Joyce, Visions of the People: Industrial England and the Question of Class, 1848-1914 (Cambridge: Cambridge University Press, 1991), 230-55, 348-53, 366-67.

11 Andrew Roberts, "Preface," Pindar, Folio Book of Historic Speeches, xiii.

12 Jean Garner, By His Own Merits: Sir John Hall-Pioneer, Pastoralist and Premier (Christchurch: Dryden Press, Christchurch, 1995), 238-39.

${ }^{13}$ David Hamer, ed., The Webbs in New Zealand (Wellington: Price Milburn for University of Victoria Press, Wellington, 1974), 35.

${ }^{14}$ Evening Post, December 4, 1905, 6.

15 Sydney Morning Herald, June 12, 1906, 7.
} 
16 Bulletin, June 14, 1906, 9.

17 William Pember Reeves, The Long White Cloud: Ao-tea-roa (1898; Auckland: Golden Press, 1973), 295-96.

18 James Drummond, The Life And Work Of Richard John Seddon Premier Of New Zealand, 18931906, With A History Of The Liberal Party In New Zealand (Christchurch: Whitcombe and Tombs Ltd., 1906), 76.

19 J. B. Condliffe and W. T. G. Airey, A Short History of New Zealand, $6^{\text {th }}$ ed. (Christchurch:

Whitcombe and Tombs, 1938), 213.

20 J. C. Beaglehole, New Zealand: A Short History (London: Allen and Unwin, 1936), 57-58.

${ }^{21}$ Keith Sinclair, A History of New Zealand, $2^{\text {nd }}$ ed. (Ringwood, Victoria: Penguin, 1969), 177.

${ }^{22}$ See Jock Phillips and Terry Hearn, Settlers: New Zealand Immigrants from England, Ireland and

Scotland 1800-1945 (Wellington: Ministry of Culture and Heritage, 2006), 69-72.

${ }^{23}$ From Biagini, Liberty, Retrenchment and Reform; and Joyce, Visions of the People.

${ }^{24}$ St Helens Newspaper, July 8, 1902, 134.

25 "Seddon Impersonator," BCNZ Archives, Christchurch, T 274. Recorded on the home cylinder of Fred M. Jones Junior.

${ }^{26}$ Alec and Marion McCully. On inspectors' complaints regarding regional accents made in 1861, see Joyce, Visions of the People, 201. On both "received English" and the northern voice and the

"Pygmalion trope," see Katie Wales, Northern English: A Social and Cultural History(Cambridge: Cambridge University Press, 2006), 141-45. She classifies the St Helens dialect as an example of the "central Lancashire" dialect that is distinctly different from the Liverpool one.

${ }^{27}$ See Wales, Northern English, 144-45.

${ }^{28}$ Joyce, Visions of the People, 267-78.

${ }^{29}$ Both Seddon and James Carroll complained that Grey's speeches were often fanciful and totally out of touch with practical politics. See, for example, New Zealand Parliamentary Debates 1892, 77, 269 (Seddon) and New Zealand Parliamentary Debates 1892, 78, 632 (Carroll).

${ }^{30}$ New Zealand Tablet, October 6, 1893, 17.

31 W. P. Morrell, New Zealand (London: Ernest Benn Ltd., 1935), 78-79.

${ }^{32}$ W. H. Oliver, The Story of New Zealand (London: Faber and Faber, 1960), 152.

${ }^{33}$ Bronwyn Dalley and Gavin McLean, eds, Frontier of Dreams: The Story of New Zealand (Auckland: Television New Zealand and Hodder Moa, 2005), 197, 203.

${ }^{34}$ The Otago Daily Times summarized the speech in 14 lines, while the Otago Witness ignored it altogether; the Press gave it a more generous 33 lines, but concentrated on Seddon's attack against a fellow West Coast MHR, Edward Masters: Otago Daily Times, October 3,1879, 2; Press, October 4, $1879,3$.

${ }^{35}$ New Zealand Herald, October 3, 1879, 4.

${ }^{36}$ Evening Post, October 3, 1879, 2.

${ }^{37}$ New Zealand Times, August 19, 1880, 2. The author, with equal lack of subtlety, called himself the nonsensical "Kai wai wai."

${ }^{38}$ West Coast Times, October 4, 1879, 2.

${ }^{39}$ On Gladstone's moralistic tone, see Biagini, Liberty, Retrenchment and Reform.

${ }^{40}$ New Zealand Parliamentary Debates 1879, 32, 118.

${ }^{41}$ New Zealand Parliamentary Debates 1879, 32, 111-21.

${ }^{42}$ New Zealand Parliamentary Debates 1881, 40, 316.

${ }^{43}$ New Zealand Parliamentary Debates 1881, 40, 314-20.

${ }^{44}$ Otago Daily Times, September 26, 1881, 3.

${ }^{45}$ Press, September 20, 1881, 3. The same article states that the Timaru Herald was equally rude, reporting Seddon saying "I ham" ... "hastonished at the hattitude of the Government" ... "I ham so." ${ }^{46}$ New Zealand Parliamentary Debates 1881, 40, 824.

${ }^{47}$ R. M. Burdon, King Dick: A Biography of Richard John Seddon (Christchurch: Whitcombe and Tombs, 1955), 75.

48 Rodney Lyon, "The Principles of New Zealand Liberal Thinking in the Late Nineteenth Century," (PhD thesis, University of Auckland, 1982).

${ }^{49}$ See M. J. D. Roberts, Making English Morals: Voluntary Association and Moral Reform in England (Cambridge: Cambridge University Press, 2004), 62, 193.

${ }^{50}$ Robert Chambers, ed., Cyclopaedia of English Literature: A History, Critical And Biographical, Of British Authors From The Earliest Times To the Present Times, Volume 1 (1843; William and Robert Chambers, London and Edinburgh, 1860), "The Personal Library of Richard John Seddon,” J. C. 
Beaglehole Room, Victoria University of Wellington Library, Box 1. The poems marked include extracts from Piers Plowman, select characters from Chaucer's Canterbury Tales, Sydney's sonnets, Milton's "L'Allegro," "Il Penseroso" and from "Lycidas," and Gray's "Elegy Written in a Country Churchyard." Volume 2, starting from 1760, is untouched!

${ }^{51}$ New Zealand Parliamentary Debates 1890, 68, 524. On the reading preferences of popular Liberals, see Biagini, Liberty, Retrenchment and Reform and Joyce, Visions of the People.

${ }^{52}$ New Zealand Parliamentary Debates 1890, 67, 515-28.

53 See Tom Brooking, "Use It or lose It: Unravelling the Land Debate in Late Nineteenth-Century New Zealand," New Zealand Journal of History 30, no. 2 (1996), 141-63.

54 Joyce, Visions of the People, 230-255, 348-353, 366-67.

55 Garner, By His Own Merits, 238-39.

${ }^{56}$ Pall Mall Gazette, June 5, 1897; Daily Telegraph, June 5, 1897; Empire, June 5, 1897; Newcastle Chronicle, June 7, 1897; Nottingham Guardian, June 7, 1897; in "Misc 1897 Correspondence mainly related to the London Trip," Seddon Papers, Folder 24, MS 1619, Alexander Turnbull Library, Wellington. Macaulay's whimsical moment was made more famous by Gustave Doré's engraving of the scene, published in 1872: see David Skilton, "Contemplating the Ruins of London: Macaulay's New Zealander and Others," http://homepages.gold.ac.uk/london-journal/march2004/skilton.html ${ }^{57}$ Evening Post, July 20, 1897, 6.

${ }^{58}$ Evening Post, August 7, 1897, 1

${ }^{59}$ Evening Post, September 10, 1897, 2.

${ }^{60}$ John Darwin, The Empire Project: The Rise and Fall of the British World System, 1830-1970 (Cambridge: Cambridge University Press, 2009), 176.

${ }^{61}$ The Times, August 8, 1902, 6.

${ }^{62}$ New Zealand Parliamentary Debates 1903, 126, 704.

${ }^{63}$ New Zealand Parliamentary Debates 1903, 126, 713.

${ }^{64}$ Donald A. Worster, A Passion for Nature: A Life of John Muir (Oxford: Oxford University Press, New York, 2008), 32.

${ }^{65}$ David Daiches, Robert Burns and His World (London: Thames and Hudson, 1978), 50-51; Susan Murray, "Burns and God," in Robert Burns and Cultural Authority, ed. Robert Crawford (Edinburgh: Edinburgh University Press, 1997), 130; and Liam McIlvanney, The Radical Burns: Poetry and Politics in Late Eighteenth-Century Scotland (Phantassie, East Lothian: Tuckwell Press, 2002), 110. ${ }^{66}$ Drummond, Life And Work Of Richard John Seddon, 3-4; Burdon, King Dick, 2; St Helens Newspaper, August 29, 1902, 205-6.

${ }^{67}$ Seddon, quoted in New Zealand Times, October 18, 1902, 18, and Evening Post, May 1, 1906, 5. See also Weekly Press, June 20, 1906, 36 and St Helens Newspaper, August 26, 1902, 207.

68 On the exclusively white character of Australian utopianism, see Bruce Scates, A New Australia: Citizenship, Radicalism, and the First Republic (Cambridge: Cambridge University Press, 1997); on practical utopianism, see Leon Fink, Workingmen's Democracy: The Knights of Labor and American Politics (Urbana: University of Illinois Press, 1983) and Steve Leiken, The Practical Utopians: American Workers and the Cooperative Movement in the Gilded Age (Detroit: Wayne State University Press, 2005).

${ }^{69}$ Sydney Daily Telegraph, May 19, 1906, 9.

70 Pindar, Folio Book of Historic Speeches, xix. 